\title{
EFFECTS OF POLYMYXIN ANTIBIOTICS ON IODOHIPPURATE ACCUMULATION IN RABBIT RENAL CORTICAL SLICES
}

\author{
Nils Milman and Jørgen Dahlager \\ Division of Nephrology, Department of Medicine P and Division of Urology, \\ Department of Surgery D, Rigshospitalet (Copenhagen University Hospital), \\ Copenhagen, Denmark
}

(Received for publication June 12, 1978)

\begin{abstract}
The in vitro effects of polymyxin antibiotics on $o^{-125} \mathrm{I}$-hippurate $(\mathrm{OIH})$ accumulation in rabbit renal cortical slices were studied using incubation media with $\mathrm{pH}$ ranging from 6.9 to 7.9 and containing polymyxin B sulfate, colistin sulfate, sodium colistimethate and antibacterially inactive $\mathrm{N}$-succinyl colistin in concentrations ranging from 1 to $2,000 \mu \mathrm{g}$ base $/ \mathrm{ml}$. Polymyxin B, colistin and colistimethate depressed OIH accumulation significantly in concentrations $\geq 300 \mu \mathrm{g} / \mathrm{ml}$. The effects on accumulation were clearly pH-dependent and most pronounced at alkaline $\mathrm{pH}$. N-Succinyl colistin had only a marginal influence on accumulation, even in high concentrations. Colistimethate produced a significantly smaller decrease in accumulation at all $\mathrm{pH}$ values than both polymyxin B and colistin. The results suggest that the presence of free amino groups is necessary to obtain a decrease in accumulation and correlate with the known in vivo nephrotoxicity of these antibiotics.
\end{abstract}

The polymyxins are cyclic polypeptide antibiotics, effective against a wide range of Gram-negative bacteria. The most used members of this group in human therapy are polymyxin $\mathbf{B}$, colistin, and colistimethate which is a methane sulfonate derivative of colistin. All polymyxins possess nephrotoxic properties, as demonstrated in animal experiments ${ }^{1)}$ and experiences from the human clinic.. ${ }^{2,3)}$ The nephrotoxicity is characterized by a spectrum of tubular damages, from slight degenerative changes to frank tubular necrosis. ${ }^{1,2,3)}$ In the present study the effects of various polymyxins on the $O{ }^{-125} \mathrm{I}-$ hippurate (OIH) accumulation in rabbit renal cortical slices have been assessed in an attempt to elucidate further the nephrotoxicity of these antibiotics.

\section{Materials and Methods}

Measurement of $o^{-125} \mathrm{I}$-hippurate accumulation:

The technique employed is a modification of the method reported by Cross and TAGGART, ${ }^{4)}$ and has been described in details elsewhere. ${ }^{5}$ ) Rabbit renal cortical slices were incubated in Erlenmeyer vessels for 60 minutes at $25^{\circ} \mathrm{C}$ with $100 \%$ oxygen in the gas space, while being shaken at 100 cycles/ minute. Each vessel contained $90 \sim 110 \mathrm{mg}$ slices, $10 \mathrm{ml}$ Cross-TAGGART medium ${ }^{4)}$ and $20 \mu \mathrm{Ci} o^{-{ }^{125}} \mathrm{I}-$ hippurate/liter corresponding to approximately $3 \mu \mathrm{mol} / \mathrm{liter}$. The slices and aliquots of the incubation media were counted in a gamma scintillation counter and the OIH accumulation expressed as the slice to medium ratio i.e. the ratio of the counts in $1 \mathrm{~g}$ tissue to those in $1 \mathrm{ml}$ incubation medium.

Polymyxin studies:

All the polymyxin substances employed were kindly provided by Dumex Ltd., Copenhagen, Denmark. N-succinyl colistin sodium was obtained from colistin base, which was dissolved in pyridine, and incubated at ambient temperature for 2 weeks after the addition of succinic anhydride, whereafter $\mathrm{N}$-succinyl colistin was precipitated with ether. By this procedure approximately $98 \%$ of the free amino groups were blockaded and the antibacterial activity almost abolished. By disc assays with Bordetella bronchiseptica, N-succinyl colistin had an antibacterial activity equivalent to $0.02 \mu \mathrm{g}$ colistin 
base/mg substance, as compared to colistin sulfate having an activity of $633 \mu \mathrm{g}$ base/mg substance. The calculated (antibacterially inactive) base content in N-succinyl colistin was $621 \mu \mathrm{g} / \mathrm{mg}$ substance.

Prior to incubation the following polymyxins were added to the incubation media in concentrations ranging from 1 to $2,000 \mu \mathrm{g}$ base $/ \mathrm{ml}$ : Polymyxin B sulfate ( $800 \mu \mathrm{g}$ base $/ \mathrm{mg}$ ), colistin sulfate (633 $\mu \mathrm{g}$ base $/ \mathrm{mg}$ ), sodium colistimethate (456 $\mu \mathrm{g}$ base $/ \mathrm{mg}$ ) and $\mathrm{N}$-succinyl colistin sodium ( $621 \mu \mathrm{g}$ calculated base/mg). Hereafter $\mathrm{pH}$ was adjusted to $6.9,7.4$ and 7.9 by means of $2 \mathrm{~N}$ hydrochloric acid or $2 \mathrm{~N}$ sodium hydroxide and using a $\mathrm{pH}$-meter. Incubation was then performed as described above. All experiments were done $6 \sim 8$ times and each setup included control vessels without polymyxins. The OIH accumulation in the polymyxin-containing vessels was expressed in per cent of the accumulation in the controls.

STUDENT's $t$-test for paired and unpaired values was employed in statistical evaluation of the results and the $5 \%$ value chosen as the level of significance.

\section{Results}

The results are summarized in Table 1 and Fig. 1 . The antibacterially active polymyxins inhibited $\mathrm{OIH}$ accumulation in high concentrations. The effects were clearly $\mathrm{pH}$-dependent and most pronounced at alkaline $\mathrm{pH}$.

Polymyxin B: The OIH accumulation was significantly depressed at all $\mathrm{pH}$ values by concentrations $\geq 300 \mu \mathrm{g} / \mathrm{ml}$. At concentrations $\geq 300 \mu \mathrm{g} / \mathrm{ml}$, elevation of $\mathrm{pH}$ from 6.9 to 7.4 and 7.9 significantly accentuated the decrease in accumulation produced by identical concentrations of polymyxin B. At pH 7.9 and $2,000 \mu \mathrm{g} / \mathrm{ml}$ accumulation was only $2.0 \%$ i.e. almost completely inhibited.

Colistin: Concentrations $\geq 300 \mu \mathrm{g} / \mathrm{ml}$ depressed accumulation distinctly at all $\mathrm{pH}$ values. At concentrations $\geq 500 \mu \mathrm{g} / \mathrm{ml}$ the effect was significantly more pronounced at $\mathrm{pH} 7.9$ compared to $\mathrm{pH} 7.4$ and 6.9. At $\mathrm{pH} 7.9,2,000 \mu \mathrm{g} /$ $\mathrm{ml}$ depressed accumulation to $4.6 \%$. There was no significant difference between the accumulation profiles (dose response curves) of polymyxin $\mathrm{B}$ and colistin at $\mathrm{pH} 6.9$ and 7.4. However, at pH 7.9 colistin depressed accumulation significantly less than polymyxin $\mathrm{B}$ at concentrations $\geq 300 \mu \mathrm{g} / \mathrm{ml}$.

Colistimethate: Accumulation was moderately but significantly depressed by concentrations $\geq 300 \mu \mathrm{g} / \mathrm{ml}$. The influence of $\mathrm{pH}$ variations was less pronounced than for polymyxin $\mathbf{B}$ and colistin and apparent only at concentrations $\geq 1,000 \mu \mathrm{g} / \mathrm{ml}$; the differences, however, were insignificant. At $\mathrm{pH} 7.9,2,000 \mu \mathrm{g} / \mathrm{ml}$ depressed accumulation to $46.4 \%$. Colistimethate produced a significantly smaller decrease in accumulation at all $\mathrm{pH}$ values and concentrations $\geq 300$ $\mu \mathrm{g} / \mathrm{ml}$ than both polymyxin B and colistin.

N-Succinyl colistin: At pH 6.9 OIH ac-

Fig. 1. Effects of different concentrations of polymyxin B sulfate, colistin sulfate, colistimethate sodium and $\mathrm{N}$-succinyl colistin sodium on ${ }^{125} \mathrm{I}$ hippurate accumulation in rabbit renal cortical slices at various $\mathrm{pH}$-values in the incubation media.

Results are expressed in per cent of the accumulation in antibiotic free controls.

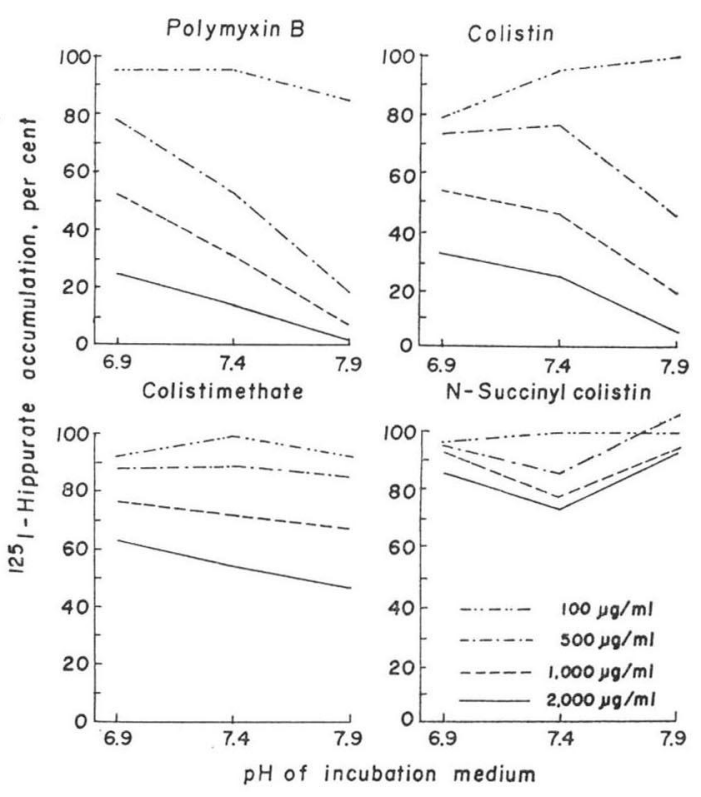


Table 1. Effects of polymyxin B sulfate, colistin sulfate, colistimethate sodium and N-succinyl colistin sodium on ${ }^{125} \mathrm{I}$-hippurate accumulation in rabbit renal cortical slices at different $\mathrm{pH}$-values in the incubation media. Results are expressed in per cent of the accumulation in antibiotic free controls (mean $\pm \mathrm{S}$. E.M.).

\begin{tabular}{|c|c|c|c|c|c|c|c|c|c|c|c|c|}
\hline \multirow{3}{*}{$\begin{array}{c}\text { Polymyxin } \\
\text { base } \\
\mu \mathrm{g} / \mathrm{ml}\end{array}$} & \multicolumn{12}{|c|}{${ }^{125}$ I-Hippurate accumulation, per cent } \\
\hline & \multicolumn{3}{|c|}{ Polymyxin B } & \multicolumn{3}{|c|}{ Colistin } & \multicolumn{3}{|c|}{ Colistimethate } & \multicolumn{3}{|c|}{ N-Succinyl colistin } \\
\hline & $\mathrm{pH} 6.9$ & pH 7.4 & pH 7.9 & pH 6.9 & $\mathrm{pH} 7.4$ & pH 7.9 & pH 6.9 & pH 7.4 & pH 7.9 & pH 6.9 & pH 7.4 & pH 7.9 \\
\hline 1 & $\begin{array}{r}98.8 \\
+5.8\end{array}$ & $\begin{array}{r}93.1 \\
\pm 5.2\end{array}$ & & $\begin{array}{r}89.7 \\
\pm 5.9\end{array}$ & $\begin{array}{r}92.2 \\
\pm 4.3\end{array}$ & \pm & 5 & $\begin{array}{r}109.4 \\
\pm 3.4\end{array}$ & & & & \\
\hline 10 & $\begin{array}{r}95.2 \\
\pm 3.3\end{array}$ & $\begin{array}{l}9 \\
\pm\end{array}$ & & 9 & & & & & & & & \\
\hline 100 & $\begin{array}{r}94.9 \\
\pm 5.1\end{array}$ & $\begin{array}{r}94.9 \\
\pm 6.6\end{array}$ & $\begin{array}{c}84.5 \\
\pm 6.4^{*}\end{array}$ & $\begin{array}{c}79.1 \\
\pm 5.0 *\end{array}$ & $\begin{array}{r}95.4 \\
\pm 5.0\end{array}$ & $\begin{array}{r}99.9 \\
\pm 3.1\end{array}$ & $\begin{array}{r}91.9 \\
\pm 2.2\end{array}$ & $\begin{array}{r}99.4 \\
\pm 2.3\end{array}$ & $\begin{array}{r}92.2 \\
\pm 4.7\end{array}$ & $\begin{array}{r}96.6 \\
\pm 3.7\end{array}$ & .6 & \\
\hline 300 & $\begin{array}{c}86.9 \\
\pm 3.0 *\end{array}$ & $\begin{array}{c}82.3 \\
\pm 5.9 *\end{array}$ & $\begin{array}{c}32.6 \\
\pm 7.0 *\end{array}$ & $\begin{array}{c}77.5 \\
\pm 5.0 *\end{array}$ & $\begin{array}{c}80.9 \\
\pm 4.7 *\end{array}$ & $\begin{array}{c}76.7 \\
\pm 3.3 *\end{array}$ & $\begin{array}{r}91.9 \\
\pm 2.2\end{array}$ & $\begin{array}{l}89.3 \\
\pm 3.7 *\end{array}$ & \begin{tabular}{|}
84.6 \\
$\pm 5.6 *$
\end{tabular} & $\begin{array}{r}93.0 \\
\pm 3.3\end{array}$ & $\begin{array}{c}99.5 \\
\pm 3.9 *\end{array}$ & \\
\hline 500 & $\begin{array}{c}77.8 \\
\pm 0.8 *\end{array}$ & $\begin{array}{c}52.5 \\
\pm 3.3 *\end{array}$ & $\begin{array}{c}18.2 \\
\pm 4.9 *\end{array}$ & $\left|\begin{array}{c}72.8 \\
\pm 2.3 *\end{array}\right|$ & $\begin{array}{c}75.9 \\
\pm 4.4^{*}\end{array}$ & $\begin{array}{c}44.9 \\
\pm 3.2 *\end{array}$ & $\begin{array}{c}88.3 \\
\pm 4.3 *\end{array}$ & $\begin{array}{c}89.0 \\
\pm 0.9 *\end{array}$ & $\begin{array}{c}85.3 \\
\pm 5.5^{*}\end{array}$ & $\begin{array}{r}96.3 \\
\pm 3.7\end{array}$ & $\begin{array}{c}86.1 \\
\pm 3.5 *\end{array}$ & $\mid \begin{array}{l}10 \\
\pm\end{array}$ \\
\hline 1,000 & $\begin{array}{c}52.2 \\
\pm 1.8 *\end{array}$ & $\begin{array}{c}30.7 \\
\pm 1.8 *\end{array}$ & $\begin{array}{r}7.2 \\
\pm 2.1^{*}\end{array}$ & $\mid \begin{array}{c}53.7 \\
\pm 1.1 *\end{array}$ & $\begin{array}{c}45.4 \\
\pm 5.3 *\end{array}$ & $\begin{array}{c}17.7 \\
\pm 2.0 *\end{array}$ & $\begin{array}{c}76.4 \\
\pm 4.3 *\end{array}$ & $\begin{array}{c}72.0 \\
\pm 2.3^{*}\end{array}$ & $\begin{array}{r}66 \\
\pm 5\end{array}$ & $\begin{array}{r}93.0 \\
\pm 2.1\end{array}$ & $\begin{array}{r}78 \\
\pm 2\end{array}$ & $\mid \begin{array}{r}9 \\
\pm\end{array}$ \\
\hline 2,000 & $\begin{array}{c}24.2 \\
\pm 1.0^{*}\end{array}$ & $\begin{array}{l}13.8 \\
\pm 2.8 *\end{array}$ & $\begin{array}{c}2.0 \\
\pm 0.4^{*}\end{array}$ & $\begin{array}{c}31.8 \\
\pm 2.3 *\end{array}$ & $\begin{array}{c}23.9 \\
\pm 3.5^{*}\end{array}$ & $\begin{array}{c}4.6 \\
\pm 0.5^{*}\end{array}$ & $\begin{array}{c}63.4 \\
\pm 8.3 *\end{array}$ & $\begin{array}{c}54.1 \\
\pm 2.9 *\end{array}$ & $\begin{array}{c}46.4 \\
\pm 3.5^{*}\end{array}$ & $\begin{array}{c}86.2 \\
\pm 3.2^{*}\end{array}$ & $\begin{array}{c}74.3 \\
\pm 2.9 *\end{array}$ & $\begin{array}{r}94.3 \\
\pm 6.9\end{array}$ \\
\hline
\end{tabular}

* $\mathrm{P}<0.05$

cumulation was slightly depressed by $2,000 \mu \mathrm{g} / \mathrm{ml}$. At pH 7.4 accumulation decreased moderately at concentrations $\geq 500 \mu \mathrm{g} / \mathrm{ml}$. However, at $\mathrm{pH} 7.9$ even high concentrations had no influence on accumulation, being $94.3 \%$ at $2,000 \mu \mathrm{g} / \mathrm{ml}$. N-Succinyl colistin had a significantly smaller effect on accumulation than both polymyxin B, colistin and (to a lesser extent) colistimethate.

\section{Discussion}

The accumulation of $p$-aminohippurate and $\mathrm{OIH}$ is a metabolic characteristic of the proximal tubular cell ${ }^{4}$, involving an active transport of $p$-aminohippurate across the peritubular membrane, followed by diffusion through the luminal membrane into the tubular fluid. ${ }^{6}{ }^{2}$ The $p$-aminohippurate transport system is energy requiring and closely connected with oxygen utilization ${ }^{4,7)}$ and is common to numerous organic acids, which compete with each other about the transport capacity. ${ }^{8)}$

The mechanisms responsible for the polymyxin-induced effects on $\mathrm{OIH}$ accumulation are unclarified, but seem to imply the presence of free amino groups. Inactivation of the amino groups by $\mathrm{N}$-succinylation almost eliminates the inhibitory influence on accumulation.

The antibacterial properties of the polymyxins are effected through interaction with phospholipids, especially phosphatidylethanolamine groups in bacterial membranes and subsequent damage to membrane function. ${ }^{9)}$ These antibiotics also interact with phospholipids in mammalian cell membranes..$^{9,10,11)}$ Impairment of the tubular cell membrane might affect the function of the $\mathrm{OIH}$ receptor sites, ${ }^{12)}$ causing decreased influx of $\mathrm{OIH}$, and might also increase membrane permeability and thereby the efflux of OIH.

The results demonstrate that the influence of polymyxins on $\mathrm{OIH}$ accumulation is pH-dependent and most pronounced at alkaline $\mathrm{pH}$. An increase in $\mathrm{pH}$ reduces the number of protonated amino groups and thus facilitates diffusion into and through the cell membrane according to the theory of nonionic diffusion. ${ }^{13)}$ Furthermore the binding of polymyxins to phospholipids shows a $\mathrm{pH}$ optimum 
around $7.5 \sim 8.0$, suggesting that the antibacterial and toxic effects depend on a certain balance between protonated and unprotonated amino groups in the molecule. ${ }^{9)}$ In accordance with these considerations the influence of $\mathrm{N}$-succinyl colistin, where the amino groups have been inactivated and which has almost no antibacterial properties, on $\mathrm{OIH}$ accumulation is marginal and on the whole $\mathrm{pH}$-independent.

Polymyxin B and colistin, but not colistimethate, are bound to and inhibited by rabbit kidney homogenates, and subcellular fractions containing mitochondria and lysosomes are the most potent inhibitors ${ }^{11)}$; also polymyxins bind strongly to nucleic acids. ${ }^{92}$ It is usually assumed that polymyxins penetrate poorly into cells ${ }^{9}$. However, polymyxin $\mathbf{B}$ accumulate in high concentrations in the kidney ${ }^{14)}$ where it is retained for considerable time and most likely part of this is situated intracellularly, where it through binding to important structures might impair metabolic processes involved with OIH accumulation.

Mutual substrate competition between polymyxins and $\mathrm{OIH}$ seems unlikely in view of previous studies ${ }^{5}$ and the observation that urinary excretion of these drugs is unaffected by probenecid. ${ }^{15,17)}$ The proximal tubular cells also possess a transport system for organic bases, ${ }^{8}$ ) but the affinity of polymyxins to this system is unknown.

When equimolar base concentrations were compared, polymyxin B and colistin had almost identical and much greater depressive effects on $\mathrm{OIH}$ accumulation than colistimethate. The in vitro results thus correlate with the recognized in vivo nephrotoxicity of these drugs. ${ }^{17,18)}$ The degree of tissue binding, toxicity and antibacterial activity are closely related to the number of free amino groups. ${ }^{19,20)}$ Polymyxin B and colistin each contains 5 free amino groups per molecule. In colistimethate 3 to 4 of these have been combined with methane sulfonate (Dumex Ltd., personal communication), causing a reduction in tissue binding ${ }^{20)}$ as well as in nephrotoxicity ${ }^{17}{ }^{18)}$ and antibacterial activity. ${ }^{19}$ )

The high tissue binding ${ }^{13,20)}$ and consequent inactivation of the antibacterial effect, and the lack of suitable assays have impeded exact pharmacokinetic studies of the polymyxins. Colistimethate is probably eliminated mainly by glomerular filtration ${ }^{15}$, although the extent of transtubular transport is unclarified. Ionic diffusion trapping has apparently no influence on the urinary excretion, which is unaffected by variations in urinary $\mathrm{pH}^{15}{ }^{15}$ ) However, the protective effect of D-glucarates suggests that the degree of protonation plays some kind of a role in colistimethate nephrotoxicity. ${ }^{21}$ )

\section{References}

1) Moyer, J. H.; L. C. Mills \& E. M. Yow: Toxicity of polymyxin B. I. Animal studies with particular reference to renal function. Arch. Intern. Med. 92: 238 247, 1953

2) Koch-Weser, J.; V. W. Sidel, E. B. Federman, P. Kanarek, D. C. Finer \& A. E. Eaton: Adverse effects of sodium colistimethate. Manifestations and specific reaction rates during 317 courses of therapy. Ann. Intern. Med. 72: 857 868, 1970

3) Ryan, K. J.; L. I. Schainuck, R. O. Hickman \& G. E. Striker: Colistimethate toxicity. Report of a fatal case in a previously healthy child. J. Amer. Med. Ass. 207: 2099 2101, 1969

4) Cross, R. J. \& J. V. TAGgarT: Renal tubular transport: Accumulation of p-aminohippurate by rabbit kidney slices. Am. J. Physiol. 161: 181 190, 1950

5) Dahlager, J. \& N. Milman: Aminoglycoside nephrotoxicity. I. Effects of aminoglycoside antibiotics on iodohippurate accumulation in rabbit renal cortical slices. J. Antibiotics 30: 597 603, 1977

6) Tune, B. M.; M. B. Burg \& C. S. PAtlak: Characteristics of $p$-aminohippurate transport in proximal renal tubules. Am. J. Physiol. 217: 1057 1063, 1969

7) Maxild, J. \& J. Møller: Metabolic studies on renal transport of p-aminohippurate in vitro. Biochem. Biophys. Acta 184: 613 624, 1969

8) LANT, R. F.: $\quad$ Renal excretion and nephrotoxicity of drugs. pp. 591 614. In D. Black (ed), Renal disease. Blackwell Scientific Publications, London, 1972

9) Feingold, D. S.; C. C. Hsuchen \& I. J. Sud: Basis for the selectivity of action of the polymyxin antibiotics on cell membranes. Ann. N.Y. Acad. Sci. 235: 480 491, 1974

10) Hasselbarth, A.: Effect of polymyxin B on the replication of poliovirus in cell cultures. Med. Microbiol. Immunol. 157: 239 243, 1972

11) Kunin, C. M.: Binding of antibiotics to tissue homogenates. J. Infect. Dis. 121: 55 64, 1970

12) Berner, W. \& R. KINNE: Transport of $p$-aminohippuric acid by plasma membrane vesicles isolated from 
rat kidney cortex. Pflügers Arch. 361: 269 277, 1976

13) Weiner, J. M. \& G. H. Mudge: Renal tubular mechanisms for excretion of organic acids and bases. Am. J. Med. 36: 743 762, 1964

14) Jacobson, M.; A. Koch, R. Kuntzman \& J. Burchall: The distribution and binding of tritiated polymyxin B in the mouse. J. Pharmacol. Exp. Ther. 183: 433 439, 1972

15) Al-Khayyat, A. A. \& A. L. Aronson: Pharmacologic and toxicologic studies with the polymyxins. II. Comparative pharmacologic studies of the sulfate and methanesulfonate salts of polymyxin B and colistin in dogs. Chemotherapy 19: 82 97, 1973

16) Caldwell, A. D. S.; A. J. Martin \& D. J. Trigger: Comparative study of the effect of three antibiotics on renal function. Brit. J. Pharmacol. 37: 283 293, 1969

17) Pedersen, M. F.; J. F. Pedersen \& P. O. Madsen: A clinical and experimental comparative study of sodium colistimethate and polymyxin B sulfate. Invest. Urol. 9: 234 237, 1971

18) Vinnicombe, J. \& T. A. StameY: The relative nephrotoxicities of polymyxin B sulfate, sodium sulfomethyl-polymyxin B, sodium sulfomethyl-colistin (colymycin), and neomycin sulfate. Invest. Urol. 6: $505 \sim 519,1969$

19) Nord, N. M. \& P. D. Hoeprich: Polymyxin B and colistin. A critical comparison. New Eng. J. Med. 270: $1030 \sim 1035,1964$

20) Kunin, C. M. \& A. Bugg: Recovery of tissue bound polymyxin B and colistimethate. Proc. Soc. Exp. Biol. Med. 137: 786 790, 1971

21) Furuno, K.; A. Kunio \& S. Suzuki: Effect of D-glucarates on basic antibiotic-induced renal damage in rats. J. Antibiotics 29: $187 \sim 194,1976$ 